\title{
Characterization of Management and Environmental Factors Associated with Regional Variations in Potato Zebra Chip Occurrence
}

\author{
F. Workneh, D. C. Henne, J. A. Goolsby, J. M. Crosslin, S. D. Whipple, J. D. Bradshaw, \\ A. Rashed, L. Paetzold, R. M. Harveson, and C. M. Rush
}

First, eighth, and tenth authors: Texas A\&M AgriLife Research, Bushland 79012; second author: Texas A\&M AgriLife Research, Weslaco 78596; third author: United States Department of Agriculture-Agricultural Research Service (USDA-ARS), Edinburg, TX 78596; fourth author: USDA-ARS, Prosser, WA 99350; fifth, sixth, and ninth authors: University of Nebraska, Panhandle Research and Extension Center, Scottsbluff 69361; and seventh author: University of Idaho, R\&E Center, Aberdeen 83210. Accepted for publication 8 July 2013.

\begin{abstract}
Workneh, F., Henne, D. C., Goolsby, J. A., Crosslin, J. M., Whipple, S. D., Bradshaw, J. D., Rashed, A., Paetzold, L., Harveson, R. M., and Rush, C. M. 2013. Characterization of management and environmental factors associated with regional variations in potato zebra chip occurrence. Phytopathology 103:1235-1242.

Potato zebra chip (ZC), caused by the bacterial pathogen 'Candidatus Liberibacter solanacearum', which is vectored by the potato psyllid (Bactericera cockerelli), has caused widespread damage to U.S. potato production ever since its first discovery in south Texas in 2000. To determine the influence of environmental factors and management practices on ZC occurrence, data on management and meteorological variables, field locations, and psyllid counts were collected over a 3-year period (2010 to 2012) from six locations across the central United States (south Texas to Nebraska). At these locations, ZC-symptomatic plants

tomatic plants per plot were classified into two intensity classes $(\mathrm{ZC} \leq 3$ or $\mathrm{ZC}>3$ ) and subjected to discriminant function and logistic regression analyses to determine which factors best distinguish between the two ZC intensity classes. Of all the variables, location, planting date, and maximum temperature were found to be the most important in distinguishing between ZC intensity classes. These variables correctly classified $88.5 \%$ of the fields into either of the two ZC-intensity classes. Logistic regression analysis of the individual variables showed that location accounted for $90 \%$ of the variations, followed by planting date (86\%) and maximum temperature $(70 \%)$. There was a low but significant $(r=-0.44983, P=$ $0.0211)$ negative correlation between counts of psyllids testing positive for pathogen and latitudinal locations, indicating a south-to-north declining trend in counts of psyllids testing positive for the pathogen. A similar declining trend also was observed in ZC occurrence $(r=-0.499$, $P=0.0094)$.
\end{abstract} were counted in 26 fields from systematically established $20 \mathrm{~m} \times 30 \mathrm{~m}$ plots around the field edges and field interiors. Mean numbers of symp-

Potato zebra chip (ZC), putatively caused by the $\alpha$-proteobacterium 'Candidatus Liberibacter solanacearum' (27) (syn. psyllaurous) (17), vectored by the potato psyllid Bactericera cockerelli (35), has been a major production-limiting factor in the United States ever since it was first observed in south Texas in 2000 (44). First detected in Mexico in the mid-1990s (45), the disease is now prevalent in the central and western United States, and most recently in the Pacific Northwest (PNW) (Idaho, Oregon, and Washington) $(8,10,50,54)$. Outside the United States, in addition to Mexico, ZC has been reported from New Zealand and several Central American countries $(3,27,28,42,45)$. Reviews of both the psyllid and the disease have been published $(4,29,31)$.

$\mathrm{ZC}$ is characterized by internal tuber necrosis accompanied by increased phenolics, amino acids, and reducing sugars $(35,41)$ which result in freshly cut chips and fries turning dark upon frying, rendering them unmarketable. Because the disease affects all market classes of potato, not only chipping varieties, the name $\mathrm{ZC}$ is a misnomer. Symptoms in affected raw tubers first appear at the stolon attachment end and progress to the distal end over time. In a single infected plant, symptoms appear progressively in tubers, with all tubers eventually becoming symptomatic. Aerial plant symptoms include proliferation of axillary buds and aerial tubers, shortened internodes, and leaf rolling, yellowing, and

Corresponding author: F. Workneh; E-mail address: f-workneh@tamu.edu

http://dx.doi.org/10.1094/PHYTO-03-13-0084-R

(C) 2013 The American Phytopathological Society
Additional keywords: $\alpha$-proteobacterium, ROC curve.

scorching, which is usually followed by plant death. Symptomatic plants in the field may be observed individually or in clusters of various sizes (22). Psyllid and ZC intensity distributions in potato fields are often greater on the field edges than the interior of fields $(5,52)$.

The effect of ZC on tuber yield depends on when plants become infected; plants infected early in the growing season normally produce small-sized tubers. Potato psyllids can cause substantial damage to tuber yield and quality even in the absence of ' $C a$. L. solanacearum' and not all potato psyllids test positive for the putative pathogen (34). Molecular tests conducted since 2009 overall have shown that a very small percentage $(<5 \%)$ of potato psyllids test positive for ' $C a$. L. solanacearum' $(12,20)$. Losses to ZC primarily arise from reduced quality of infected tubers that become unmarketable because of subsequent discoloration of the fried products. Potato lots which exceed $15 \%$ defects in fry tests are generally rejected by processing plants. Texas potato growers suffered substantial losses to ZC, especially during the early years of its discovery, when fields were not treated because knowledge of the causal agent and the vector was lacking. There are no commercially available resistant cultivars, although cultivars may differ in degree of susceptibility (32). Therefore, current management strategies strictly encompass the use of insecticides as pre- and post-emergence applications to limit damages caused by psyllids. Most commonly used insecticide types and spray schedules were described by Zens et al. (55).

Although ZC has been observed yearly since its discovery, the association of the putative bacterium and its psyllid vector was 
not known until recently $(28,35,46)$. Thus, there is little or no information on factors which influence its epidemiology. However, as with any disease caused by arthropod-transmitted pathogens, one would expect environmental factors which affect psyllid behavior to play a major role in the disease epidemiology. Reports of investigations conducted in the early to mid-1900s on psyllid ecology suggest that potato psyllids may not be able to overwinter in the northern United States but migrate north every spring from winter breeding areas in regions of the southern United States and northern Mexico $(43,49)$. However, although spring migration from the south cannot be ruled out, recent observations of adult potato psyllids overwintering on a wild solanaceous host in the PNW suggest that potato psyllids are capable of surviving in the northwestern United States during the winter (37). In addition, experimental studies under controlled conditions have demonstrated that potato psyllids can withstand temperatures below freezing for an extended period of time $(21,51)$, and recent trapping of psyllids in northwest Texas during cold and snowy weeks (unpublished data) verifies that psyllids are more cold tolerant than previously believed.

Potato crops are cultivated under diverse environmental conditions across the central United States. Successive planting (from south to north) normally takes place beginning in December in the Lower Rio Grande Valley of Texas and ending in May in northern regions, with respective harvest dates extending from April through September. Knowledge of the impact of the regional diversity in potato culture on $\mathrm{ZC}$ occurrence could be useful for understanding of factors which affect the epidemiology of the disease. The primary objective of this project was to identify environmental and management factors associated with $\mathrm{ZC}$ intensity across the region. Specifically, we were interested in investigating whether variation among fields in $\mathrm{ZC}$ intensity could be explained by environmental differences and management factors.

\section{MATERIALS AND METHODS}

Field locations. ZC intensity assessments were conducted in 26 commercial potato fields at six locations from south Texas to Nebraska, which included areas in the Lower Rio Grande Valley, Pearsall, Olton, and Dalhart (all in Texas), Garden City (Kansas), and Bridgeport (Nebraska), ranging in latitude from $26.44^{\circ} \mathrm{N}$ to $41.63^{\circ} \mathrm{N}$, in each of the 2010,2011 , and 2012 growing seasons. Weather stations (HOBO U30 data logger; Onset Computer Corporation, Bourne, MA) were installed at each of these six locations and weather variables were collected either remotely (where wireless cellular services were available) or manually.

ZC intensity assessments. All fields in this study were under center-pivot irrigation systems, planted to chipping cultivars, and $\approx 8$ to 50 ha in size. 'FL1867' and 'Atlantic' potato accounted for nearly $81 \%$ of the cultivars used during the 3 -year period. For ZC assessments, plots of $20 \mathrm{~m} \times 30 \mathrm{~m}$ were established systematically $(\approx 160 \mathrm{~m}$ apart) around the field edges and in the interior (half way from the edge to the center) of the fields, giving rise to two rings of plots around the center pivot. The total number of plots per field ranged from 16 to 32 , depending on the size of the fields. Numbers of symptomatic plants per plot were counted within 2 weeks of harvest and tubers from the symptomatic plants were dug, sliced from the stolon attachment end, and examined for the typical internal necrosis (diagnostic feature) symptom of $\mathrm{ZC}$ (35). If a single tuber from a plant was found to be symptomatic, the plant was considered positive for $\mathrm{ZC}$.

Psyllid counts. Potato fields used in the current study were subsets of a wider regional potato psyllid detection network in which a much greater number of fields were monitored weekly using yellow sticky traps $(12,20)$. Five yellow sticky traps on wooden stakes were installed in each field in a transect from the edge toward the center, $50 \mathrm{~m}$ apart, prior to plant emergence. The sticky traps were collected and replaced on a weekly basis. Psyllids on the sticky traps were counted under a dissecting microscope and the number of potato psyllids per trap was recorded for each field. DNA was extracted from individual psyllids and polymerase chain reaction (PCR) analysis for ' $\mathrm{Ca}$. $\mathrm{L}$. solanacearum' was run using previously published primers OA2/OI2c $(9,28)$.

Analyses. For each field, the average number of symptomatic plants per plot was used as a measure of ZC intensity. To determine the association of various factors with $\mathrm{ZC}$ intensity levels, fields were classified into two disease-intensity categories, in which those which had $\leq 3$ symptomatic plants per plot were designated as $1(\mathrm{ZC}=1)$ and those with $>3$ were designated as 2 $(\mathrm{ZC}=2)$. Daily weather variables, weekly counts of adult psyllids (both averaged over the growing season), planting dates, field locations (GPS), and the number of insecticide applications were analyzed to determine their association with the two ZC intensity classes using discriminant function analysis (SAS statistical software; SAS Institute Inc., Cary, NC).

Discriminant function analysis is a multivariate technique which classifies response variables into one of two or more categories based on a battery of explanatory variables $(2,47)$. The analysis is robust to assumptions of normality as long as the minimum number of samples in any of the response classes is sufficiently greater than the number of subjects under consideration (47). However, it is highly sensitive to variance heterogeneity because cases tend to classify into the group with greater dispersion (47). If the variances are not homogenous, either a nonparametric option (quadratic discriminant function), which makes no assumptions of distribution, or the within-covariance matrices are used (without pooling). In this analysis, the POOL=TEST option was used in the PROC DISCRIM statement in SAS to determine whether the covariance matrices could be pooled (linear discriminant function). The test revealed that the covariance matrices could be pooled, which suggested that the variances were homogenous and, thus, a linear discriminant function was used in the analysis. Canonical discriminant analysis (PROC CANDISC) was conducted to obtain a graphical representation of the classification and the relative importance of the individual variables. In addition, analysis was conducted using logistic regression (PROC LOGISTIC), in which the receiver operating characteristic (ROC) curve was generated to individually determine each variable's contribution in terms of the predicted area under the curve. Cluster analysis was used to assess the relationships between fields in terms of type (e.g., Abamectin [Agrimek] or Pymetrozine [Fulfill]) and frequency of insecticide application. Correlation analysis was conducted to determine the relationships among the variables and also assess potential redundancy and issues of multicollinearity problems normally associated with highly correlated variables.

\section{RESULTS}

Over the 3-year period across the region, the average number of symptomatic plants per field ranged from near zero to $>50$. Although different fields were used in each of the 3 years of the assessment period, some of the field locations appeared to have consistently greater ZC intensities than others (Fig. 1). Overall, there were two general categories of $\mathrm{ZC}$ intensities: those that were near zero and those were far greater than zero. Therefore, classification of ZC intensities into $1(\mathrm{ZC} \leq 3)$ and $2(\mathrm{ZC}>3)$ was a logical approach, in addition to providing an equal number of fields for each category (13 fields in each) for robust statistical comparisons of the two categories. Mean values of latitudinal location and planting date (Table 1) had the greatest margins of difference between the two ZC intensity classes. Maximum temperature for $\mathrm{ZC}$ level class 1 was greater by $\approx 2^{\circ} \mathrm{C}$ than that for class 2 . However, minimum and average tempera- 
tures were not as distinctly different between the two ZC intensity classes. Although total psyllid population counts were greater by an average of 2 psyllids/week in class 1 than in class 2 , there were tremendous variations in psyllid counts within each ZC intensity class, as shown by the very high standard deviations (Table 1).
Correlation analysis showed that location, maximum temperature, and planting date were highly correlated (Table 2). However, there were no significant correlations among location, total psyllid numbers, and the number of insecticide applications during the season. Numbers of psyllids positive for the pathogen significantly and negatively correlated with latitudinal location,

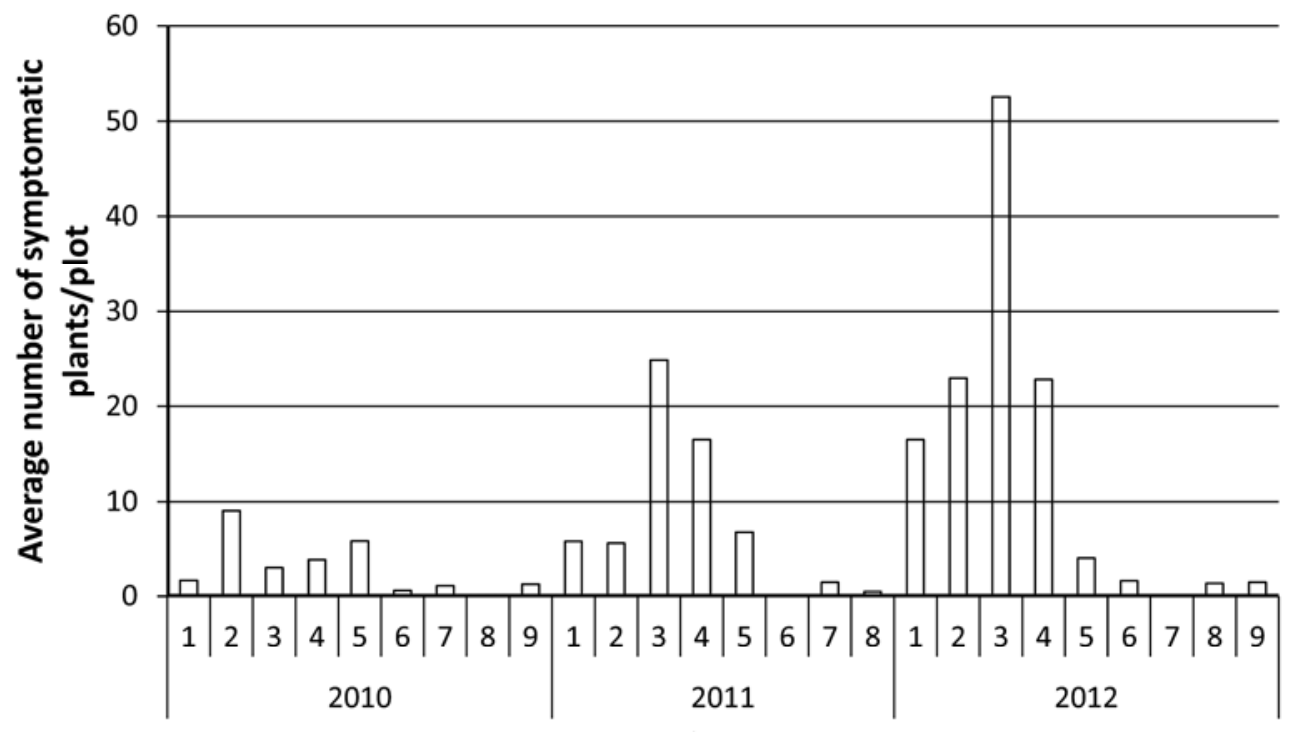

Fig. 1. Average number of symptomatic plants per plot in regionally assessed fields (labeled by numbers) from 2010 to 2012.

TABLE 1. Statistical parameters of selected variables in each of the zebra chip (ZC) intensity classes ${ }^{\mathrm{a}}$

\begin{tabular}{|c|c|c|c|c|c|c|c|c|}
\hline \multirow[b]{2}{*}{ Variable } & \multicolumn{4}{|c|}{$\mathrm{ZC}=1$} & \multicolumn{4}{|c|}{$\mathrm{ZC}=2$} \\
\hline & Mean & Max & Min & SD & Mean & Max & Min & $\mathrm{SD}$ \\
\hline Avgtemp $\left({ }^{\circ} \mathrm{C}\right)$ & 21.25 & 24.42 & 18.24 & 0.63 & 20.11 & 24.15 & 16.15 & 0.67 \\
\hline Insectap & 7.08 & 17.00 & 10.20 & 4.52 & 7.46 & 17.00 & 4.00 & 3.45 \\
\hline $\operatorname{Loc}($ Lat N) & 36.55 & 41.63 & 26.44 & 4.53 & 29.21 & 34.09 & 26.38 & 2.97 \\
\hline Maxtemp $\left({ }^{\circ} \mathrm{C}\right)$ & 29.57 & 32.78 & 24.52 & 2.76 & 27.51 & 33.04 & 24.25 & 2.85 \\
\hline Mintemp $\left({ }^{\circ} \mathrm{C}\right)$ & 12.97 & 16.86 & 10.20 & 0.68 & 13.53 & 16.14 & 9.24 & 0.62 \\
\hline Pldate (Julian) & 99.77 & 140.00 & 1.00 & 44.32 & 31.31 & 88.00 & 3.00 & 33.06 \\
\hline Ppsyllid & 0.00 & 0.00 & 0.00 & 0.00 & 1.85 & 8.00 & 0.00 & 2.51 \\
\hline Tpsyllid & 27.28 & 244.46 & 1.08 & 65.37 & 25.49 & 150.00 & 0.23 & 47.24 \\
\hline
\end{tabular}

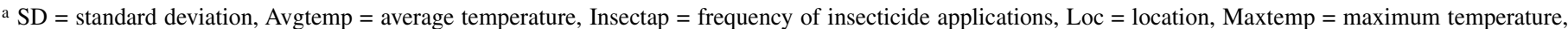

Mintemp $=$ minimum temperature, Pldate $=$ planting date, Ppsyllid = counts of psyllids positive for the pathogen, and Tpsyllid $=$ total psyllid counts .

TABLE 2. Pearson correlation coefficients and their significance levels among various variables and zebra chip (ZC) intensity levels ${ }^{\mathrm{a}}$

\begin{tabular}{|c|c|c|c|c|c|c|c|c|c|}
\hline Variable & Avgtemp & Insectap & Loc & Maxtemp & Mintemp & Pldate & Ppsyllid & Tpsyllid & $\mathrm{ZC}$ \\
\hline \multirow[t]{2}{*}{ Avgtemp } & - & 0.04528 & 0.49406 & 0.94189 & 0.71908 & 0.60655 & -0.51702 & 0.16782 & -0.28487 \\
\hline & $\ldots$ & $(0.8262)$ & $(0.0103)$ & $(<0.0001)$ & $(<0.0001)$ & $(0.0010)$ & $(0.0068)$ & $(0.4125)$ & $(0.1584)$ \\
\hline \multirow[t]{2}{*}{ Insectap } & $\ldots$ & - & -0.01847 & 0.17291 & -0.18181 & 0.057536 & -0.02799 & 0.13858 & 0.12358 \\
\hline & $\ldots$ & $\ldots$ & $(0.9286)$ & (0.3983 & $(0.3741)$ & $(0.70808)$ & $(0.8920)$ & $(0.4996)$ & $(0.5475)$ \\
\hline \multirow[t]{2}{*}{ Loc (lat. N) } & $\ldots$ & $\ldots$ & - & 0.67662 & -0.05617 & 0.93010 & -0.44983 & 0.16853 & -0.49912 \\
\hline & $\ldots$ & $\ldots$ & $\ldots$ & $(0.0001)$ & $(0.7852)$ & $(<0.0001)$ & $(0.0211)$ & $(0.4105)$ & $(0.0094)$ \\
\hline \multirow[t]{2}{*}{ Maxtemp } & $\ldots$ & $\ldots$ & $\ldots$ & - & 0.46641 & 0.76835 & -0.52317 & 0.17911 & -0.36336 \\
\hline & $\ldots$ & $\ldots$ & $\ldots$ & $\ldots$ & $(0.0163)$ & $(<0.0001)$ & $(0.0061)$ & $(0.3813)$ & $(0.0681)$ \\
\hline \multirow[t]{2}{*}{ Mintemp } & $\ldots$ & $\ldots$ & $\ldots$ & $\ldots$ & - & 0.04667 & -0.26421 & 0.12103 & 0.02205 \\
\hline & $\ldots$ & $\ldots$ & $\ldots$ & $\ldots$ & $\ldots$ & $(0.8209)$ & $(0.1921)$ & $(0.5559)$ & $(0.9149)$ \\
\hline \multirow[t]{2}{*}{ Pldate } & $\ldots$ & $\ldots$ & $\ldots$ & $\ldots$ & $\ldots$ & - & -0.46655 & 0.01513 & 0.57445 \\
\hline & $\ldots$ & $\ldots$ & $\ldots$ & $\ldots$ & $\ldots$ & $\ldots$ & $(0.0163)$ & $(0.9415)$ & $(0.0021)$ \\
\hline \multirow[t]{2}{*}{ Ppsyllid } & $\ldots$ & $\ldots$ & $\ldots$ & $\ldots$ & $\ldots$ & $\ldots$ & - & 0.04446 & 0.45814 \\
\hline & $\ldots$ & $\ldots$ & $\ldots$ & $\ldots$ & $\ldots$ & $\ldots$ & $\ldots$ & $(0.8293)$ & $(0.01860$ \\
\hline \multirow[t]{2}{*}{ Tpsyllid } & $\ldots$ & $\ldots$ & $\ldots$ & $\ldots$ & $\ldots$ & $\ldots$ & $\ldots$ & - & 0.34220 \\
\hline & $\ldots$ & $\ldots$ & $\ldots$ & $\ldots$ & $\ldots$ & $\ldots$ & $\ldots$ & $\ldots$ & $(0.34220)$ \\
\hline \multirow[t]{2}{*}{$\mathrm{ZC}$} & $\ldots$ & $\ldots$ & $\ldots$ & $\ldots$ & $\ldots$ & $\ldots$ & $\ldots$ & $\ldots$ & - \\
\hline & $\ldots$ & $\ldots$ & $\ldots$ & $\ldots$ & $\ldots$ & $\ldots$ & $\ldots$ & $\ldots$ & $\ldots$ \\
\hline
\end{tabular}

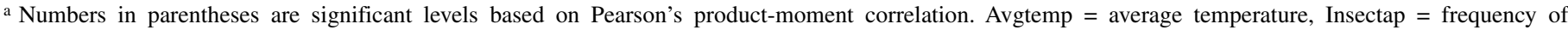
insecticide applications, Loc $=$ location, Maxtemp $=$ maximum temperature, Mintemp $=$ minimum temperature, Pldate $=$ planting date, Ppsyllid $=$ counts of psyllids positive for the pathogen, and Tpsyllid = total psyllid counts. 
planting date, and maximum temperature. Total psyllid population numbers did not correlate with psyllid numbers which were positive for ' $\mathrm{Ca}$. L. solanacearum'. ZC occurrence negatively correlated with latitudinal location and planting date but its correlation with maximum temperature was not as strong.

A linear discriminant function analysis of ZC intensities in 26 fields, with environmental and management factors as explanatory variables, strongly separated the fields into two ZC intensity classes (Wilks' $\lambda=0.4507, F=4.87, P=0.0045$ ). Of all the variables tested (Table 1), location, planting date, and maximum temperature were found to be the most important variables, as indicated by their standardized coefficients $(0.72,0.69,-0.64$, -0.03 , and -0.01 , for location, planting date, maximum temperature, total psyllid counts, and insecticide application frequency, respectively). The variables correctly classified $88.5 \%$ of the fields into two ZC intensity groups: $\mathrm{ZC} \leq 3$ or $\mathrm{ZC}>3$ symptomatic plants per plot (Table 3; Fig. 2). Removal of values of total psyllid numbers and the frequency of insecticide applications from the analysis did not significantly alter the outcome. Also, addition of average and minimum temperatures to the analysis had no effect on classification of ZC intensity.

When there are high levels of correlations among explanatory variables (as there were in this study), the values of the coefficients (see above) of individual variables are generally not accurate indicators of their contribution due to multicollinearity problems (47). Therefore, logistic regression analysis was conducted to supplement the discriminant analysis for determining individual impacts of the variables. In logistic regression, the area under the ROC curve represents the magnitude of the variable's impact; the greater the area under the curve, the greater its contribution. Plots of area under the curve for individual variables using sensitivity (the ratio of correctly classified events over total

TABLE 3. Classification of fields based on zebra chip intensity levels and percent correctly classified into the class membership as affected by various variables

\begin{tabular}{llccc}
\hline & & \multicolumn{2}{c}{ Classification } & \\
\cline { 3 - 4 } ZC class & $N$ & ZC $=1$ & ZC $=2$ & Correct $(\%)$ \\
\hline ZC $=1$ & 13 & 11 & 2 & 84.62 \\
ZC $=2$ & 13 & 1 & 12 & 92.31 \\
Total & 26 & 12 & 14 & 88.47 \\
\hline
\end{tabular}

events) versus 1-specificity (the ratio of correctly classified nonevents over total nonevents) are presented in Figure $3 \mathrm{~A}$ to $\mathrm{D}$. The event or nonevent here is $\mathrm{ZC}>3$ or $\mathrm{ZC} \leq 3$ symptomatic plants per plot, respectively. The area under the curve is represented by $\mathrm{C}$ in Table 4 . Of all the variables included in the analysis, latitudinal location had the greatest impact (Table 4; Fig. $3 \mathrm{~A}$ to D), followed by planting date and maximum temperature. Variables with $\mathrm{C}$ values of 0.7 are generally considered satisfactory whereas those with $\leq 0.8$ are considered excellent predictors (23). Values of insecticide application frequency and total psyllid population numbers failed to reach the satisfactory mark (Table 4). These ROC values of the variables were further reinforced by values of the Akaike information criterion (lower numbers indicate greater impact) and the Wald's $\chi^{2}$ statistic (Table 4; Fig. 3A to D).

In total, 24 psyllids tested positive for ' $\mathrm{Ca}$. L. solanacearum' in all 26 fields over the 3-year period. All positive psyllids were exclusively in fields which were classified as having $>3$ symptomatic plants per plot $(\mathrm{ZC}=2)$. Analysis of the impact of the variables on presence or absence of the positive psyllids provided a complete separation for which probabilities of likelihood ratios could not be estimated (23) and, thus, there were no results of the analysis. In addition, there were only eight positive psyllids which were detected 3 weeks prior to ZC assessment, which is an approximate incubation period for ZC symptom expression (34). Consequently, those which were detected within the 3-week period of the assessments could not be used for associating with the observed disease, and the numbers of those detected prior were too low for use in any multivariate analysis.

There were 18 different insecticides that were applied to the 26 fields over the 3-year period. The average number of applications was 10.2 to 17 per year. Cluster analysis of the insecticide type and application numbers provided three distinct clusters. In all, 18 of the 26 fields (69\%) were tightly clustered (Fig. 4, circles), with an average 6.9 symptomatic plants per plot, indicating that they received more or less similar insecticide types and application frequencies. This suggests that differences in insecticide usage among most of the fields across the region were not apparent in terms of effects on ZC occurrence. There were only three fields in the second cluster (square) and these fields had an average of 1.9 symptomatic plants per plot. The fields in the third cluster (triangle) had the highest ZC intensity level compared with the other two, with an average of 12.5 symptomatic plants per plot.

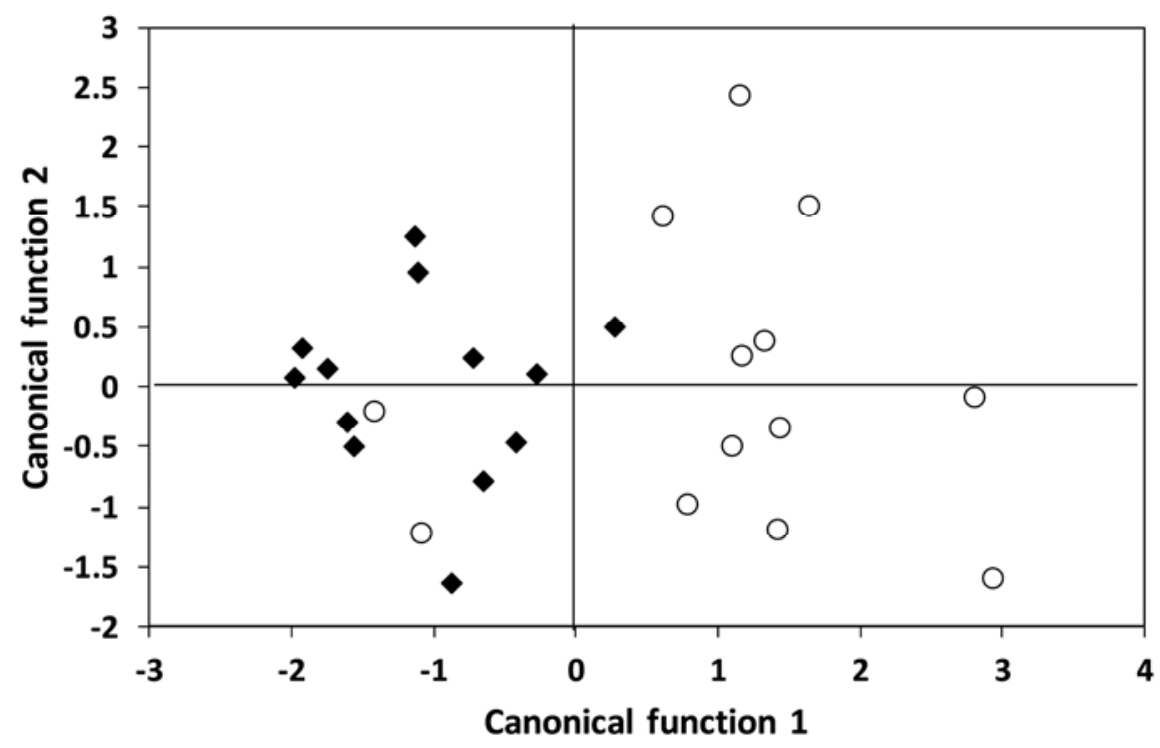

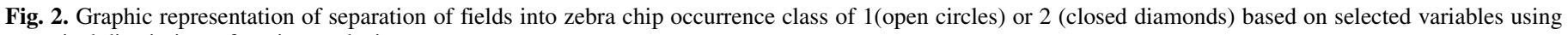
canonical discriminant function analysis. 
The figure from the cluster analysis (Fig. 4, showing similarity in insecticide application in most of the fields) is presented as a supplement to the multivariate analysis results, which indicated that insecticide application did not significantly contribute to the variation in $\mathrm{ZC}$ intensity.

\section{DISCUSSION}

Potato ZC has caused significant damage to U.S. potato production ever since its first report in south Texas in 2000 (44). The disease has been observed yearly in the central U.S. potato production regions from south Texas to Nebraska, with varying degrees of incidence. The main focus of the current study was to identify potential management and environmental factors associated with variation in occurrence of the disease across the region. The project investigated the association of geographical field locations, planting dates, weather factors, psyllid population numbers, and insecticide usage with ZC occurrence over a 3-year period.

The study identified field location, planting date, and maximum temperature as important factors, which signifies the influence of the diverse environmental conditions (under which potato crops are grown across region) on $\mathrm{ZC}$ occurrence. These three factors were highly correlated, which suggests that there is some degree of redundancy and any one of them may serve as a predictor variable for $\mathrm{ZC}$ occurrence across the region. However, location and planting date each may well be a function of temperature, although the contribution of temperature to the variability of the disease in this study was not as strong as those of location and planting date. Temperature has been reported to significantly affect psyllid reproduction (30,53) and ZC development (36). List (30) reported $27^{\circ} \mathrm{C}$ as an optimum whereas temperatures $>35^{\circ} \mathrm{C}$ inhibited egg production. Growth chamber studies conducted at various constant temperatures showed that adult psyllid development was drastically reduced at $32^{\circ} \mathrm{C}(53)$. In the southern United States, especially in south Texas, maximum temperature during the potato growing season rarely becomes a limiting factor in psyllid reproduction until late in the season (near harvest) because much of the growing season overlaps with winter. This is in sharp

TABLE 4. Statistical parameters of variables based on logistic regression analysis

\begin{tabular}{lcccc}
\hline Variable $^{\mathrm{a}}$ & $\mathrm{C}^{\mathrm{b}}$ & $\mathrm{AIC}^{\mathrm{c}}$ & $\chi^{2 \mathrm{~d}}$ & $\operatorname{Pr}>\chi^{2 \mathrm{~d}}$ \\
\hline Insectap & 0.524 & 39.79 & 0.0640 & 0.8002 \\
Location & 0.901 & 24.81 & 9.2381 & 0.0024 \\
Maxtemp & 0.703 & 37.89 & 3.0397 & 0.0786 \\
Pldate & 0.863 & 27.07 & 9.4858 & 0.0021 \\
Tpsyllid & 0.494 & 40.04 & 0.0069 & 0.9337 \\
\hline
\end{tabular}

${ }^{\mathrm{a}}$ Insectap $=$ frequency of insecticide application, Maxtemp = maximum temperature, Pldate $=$ planting date, and Tpsyllid $=$ total psyllid counts.

${ }^{\mathrm{b}} \mathrm{C}$ represents area under the receivers operating characteristic curve; the greater the area, the better the contribution of the variable.

c Akaike Information Criterion; the smaller the values the better the contribution of the variable.

d Wald's $\chi^{2}$ statistic.
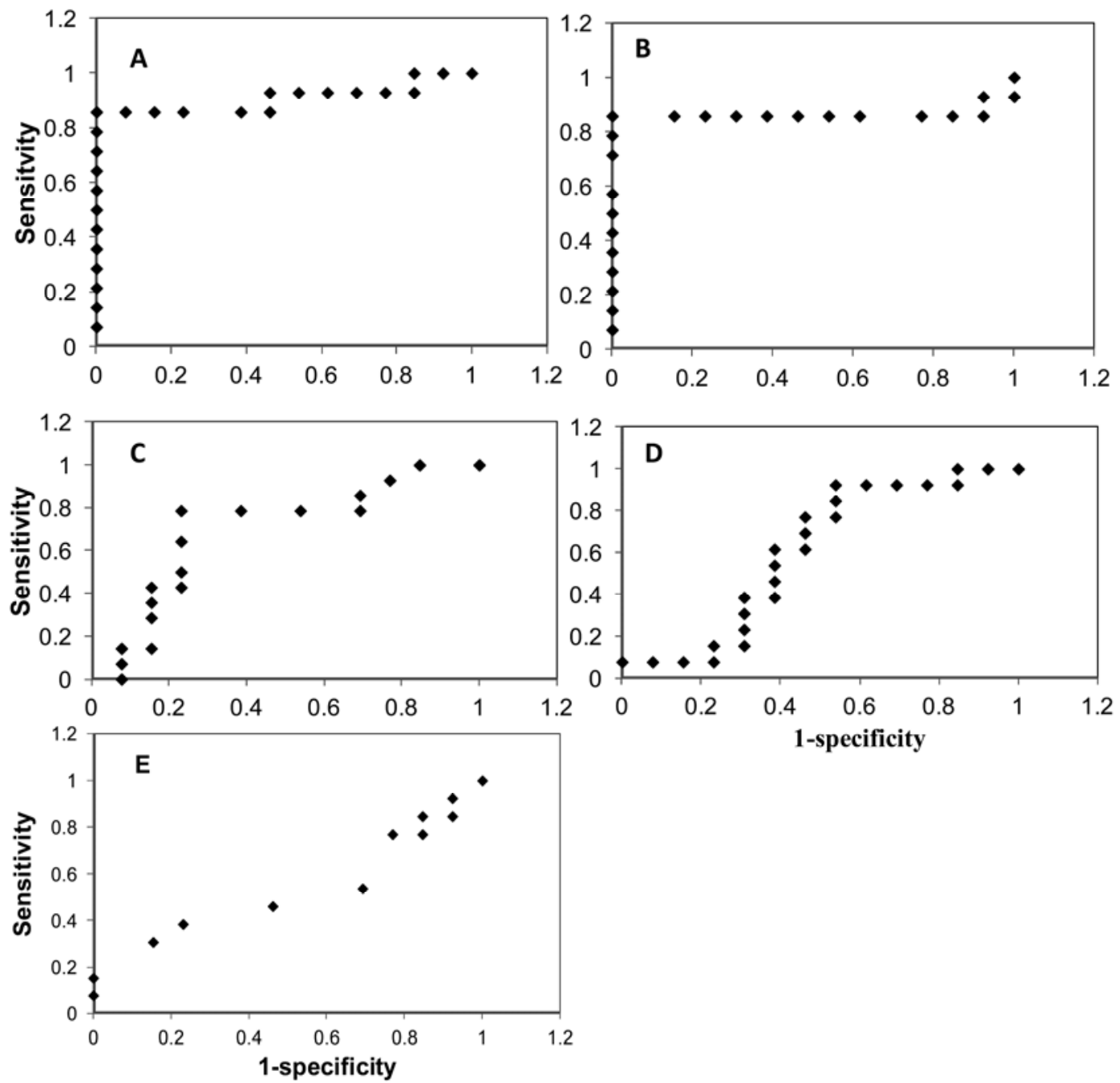

Fig. 3. Receiver operating characteristic (ROC) curves showing impact of A, location; B, planting date; C, maximum temperature; D, total psyllid population counts; and $\mathbf{E}$, insecticide type and frequency of applications on variations of zebra chip occurrence. 
contrast to the late spring and summer potato season in the north, where relatively higher temperatures predominate during much of the growing season. However, the role of fluctuating temperatures on psyllid populations and $\mathrm{ZC}$ development remains to be determined.

Alternatively, location may be an important factor by itself regardless of its correlations with planting date and temperature. Since the discovery that potato psyllids vector ' $\mathrm{Ca}$. L. solanacearum', psyllids that tested positive for the bacterium were those which were caught in south Texas early in the season $(12,20)$. In south Texas, wild solanaceous perennial hosts (e.g., Lycium and Solanum spp.) are very common and they probably support psyllids during the off season. In this region, psyllids can be detected much of the year except during the summer months, when temperatures probably exceed tolerable levels (12). It is believed that psyllids migrate out of the area during May to June, although it is possible that their population numbers may become too low to be detected. It is also possible that those testing positive may have migrated in from elsewhere (possibly northern Mexico) early and the numbers may have become diluted by mixing with noninfective resident populations as the season progressed.

Numerous studies had been conducted on survival of potato psyllids in the northern U.S. regions during the 1930s to 1950 s $(39,43,48,49)$. The general consensus from these studies was that there was no substantial evidence for survival of potato psyllids in the northern regions during the winter. It was hypothesized then that potato psyllids migrate north in the spring from the southern United States and northern Mexico, in what has been generally known as winter breeding areas (43). Although there was no direct evidence for migration, the view was reinforced by the report that potato psyllids were caught in the atmosphere at altitudes of $>1,200 \mathrm{~m}$ (11), coupled with the fact that they were routinely observed on wild solanaceous hosts in the southern United States during the winter $(43,48,49)$. Since then, it has been widely accepted that potato psyllids make yearly migrations from the southern regions to the northern regions.

The fact that there was a south-to-north declining gradient in both ZC occurrence and psyllid populations testing positive for the pathogen but not in total psyllid population counts is quite interesting. If, indeed, potato psyllids migrate north as is widely believed, the lack of location effect on the noninfective psyllids suggests that they efficiently reproduce during northward migration (following successions of potato growth). On the contrary, the fecundity and survival rates for infective psyllids are reported

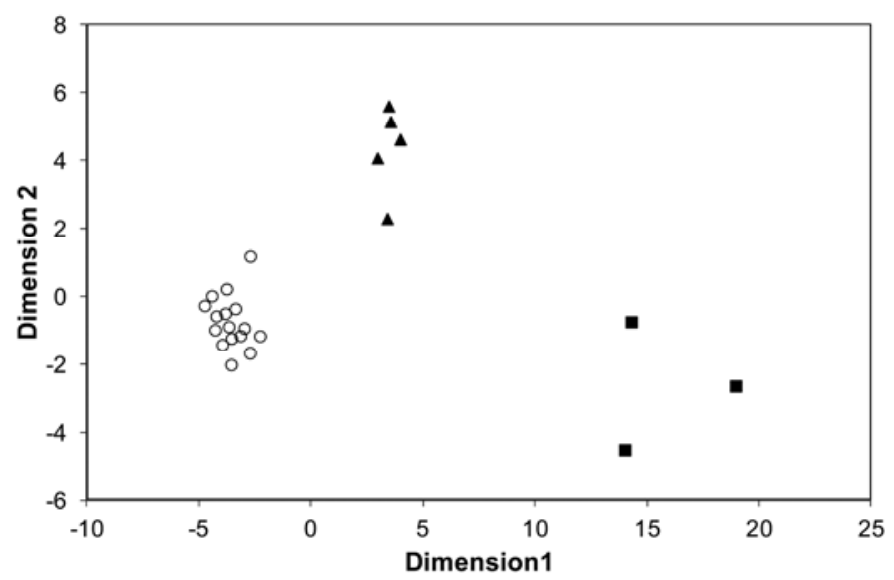

Fig. 4. Clustering of potato fields based on type and frequencies of insecticides applied showing that the majority of the fields (circles: $69 \%$ of fields) were tightly clustered, an indication of similar insecticide treatments, while the smaller two groups (triangles and squares) clustered separately from the larger group and from each other. to be significantly lower than those for noninfective ones (38), thus suggesting that their numbers may drastically decline and reach below detectable levels during migration.

Although planting date has been implicated as affecting ZC incidence (33), its association with ZC occurrence in this study appears to be due mainly to its relationship with location. Planting dates increased successively with increasing latitudinal positions from south to north and, therefore, could definitely be considered as a function of location. The current study doesn't address the effect of planting dates within a location, because that would require more time than the 3 years undertaken by this study.

Because of the historically enormous losses associated with this disease in unsprayed fields, most fields across the region were routinely sprayed to control the psyllids during the 3 years of the study. Therefore, the results presented here are from sprayed fields and, consequently, disease levels and the effect of factors presented may not accurately reflect those of unsprayed fields. However, insecticide applications did not significantly contribute to variations in disease intensity across the region, although the overall ZC level may have been reduced when one considers disease intensity levels that would have occurred if the fields were not sprayed. The primary objective for inclusion of insecticide applications (as a variable) in the current study was not for determining the type and number of insecticide applications that would provide the lowest $\mathrm{ZC}$ intensity levels but to determine whether variations in $\mathrm{ZC}$ intensity were due to differences in insecticide applications. However, the analysis methodology we used could be helpful in the future in charactering insecticide type and application frequencies in terms of their effect on $\mathrm{ZC}$ incidence with data collected over a longer time span than the 3-year period undertaken by the current study.

Sticky traps have been the most widely used tools in quantification of various insect pests under field conditions $(1,6,7,14$ $16,18,19,26,40)$. However, very few have been used for relating trap catches to incidence of diseases they are associated with, for which both significant $(1,14,26)$ and nonsignificant relationships $(7,40)$ were reported. In the current study, the lack of relationship between total psyllid numbers and ZC intensity is not surprising because a very low percentage of psyllids tested positive for the pathogen $(12,20)$. Despite the fact that a very low percentage of psyllids normally test positive for the pathogen, there have been significant losses to the disease over the years since it has been discovered. Two probable scenarios may explain what seems to be contradictory here. First, sticky traps are designed to attract flying insects nearby but may not be reliable indicators of insect populations that are already established in the field, suggesting that current detection methods are underestimating psyllid numbers in the field. Second, even if one accepts that the numbers of psyllids caught on traps are reasonable estimates of psyllid numbers in the field, it is highly probable that individual psyllids hop from plant to plant and infect several plants. If one considers that a single female could potentially have a lifespan of up to 60 days and could lay $>1,000$ eggs per season $(24,25)$, it is not difficult to imagine that very high losses could be incurred over a season even from low numbers of positive psyllids. Although there is no concrete evidence at this time, we believe that patches of infected plants often observed in the field (22) may have arisen from one or a few psyllids infecting (and laying eggs, if female) multiple contiguous plants.

Although there are no currently available resistant cultivars, Atlantic is generally considered to be more susceptible than many of the commonly grown chipping cultivars. In this study, six fields were planted to Atlantic over the 3-year period. However, removal of fields planted to the cultivar from the analysis in logistic regression did not alter the outcome. Location, planting date, and maximum temperature were still the dominant factors contributing to the variation in $\mathrm{ZC}$ intensity in the absence of the cultivar. 
The 3-year regional study revealed that potato ZC intensity was greater in the southern U.S. locations than in the northern locations and that there was a slight but significant northwarddeclining trend in disease occurrence. This is probably due to the overlap of the potato season with mild and favorable temperatures in the southern region, plus the abundance of wild perennial alternate hosts (13), which can serve as sources of the psyllids and ' $\mathrm{Ca}$. L. solanacearum'. However, there have been losses to the diseases in the past in more northerly production areas such as the Texas Panhandle, especially during the early years of the disease discovery (before control measures were implemented). Thus, a long-term study is required to fully understand the epidemiology of the disease, in association with psyllid survival and movement, and factors which affect its distribution across the region.

\section{ACKNOWLEDGMENTS}

The project was supported by USDA-SCRI grant number 2009-5118120176 and the Texas Department of Agriculture Zebra Chip Initiative. We thank the various potato growers for their support and cooperation and J. Arthur, B. Bealmer, J. Gray, and S. Pattison for their technical assistance.

\section{LITERATURE CITED}

1. Adlerz, W. C. 1976. Comparison of aphids trapped on vertical sticky board and cylindrical aphid traps and correlation with watermelon mosaic virus 2 incidence. J. Econ. Entomol.69:495-498.

2. Afifi, A., Clark, V. A., and May, S. 2004. Computer-Aided Multivariate Analysis, 4th ed. Chapman \& Hall/CRC, Boca Raton, FL.

3. Bextine, B. R., Arp, A., Flores, E. Aguilar, E.Y., Schindler, L, Freddy, S. G., Powell, C., and Rueda, A. 2013. First report of zebra chip and 'Candidatus Liberibacter solanacearum' on potatoes in Nicaragua. Plant Dis. http://dx.doi.org/10.1094/PDIS-09-12-0824-PDN

4. Butler, C. J., and Trumble, J. T. 2012. The potato psyllid, Bactericera cockerelli (Sulc) (Hemiptera: Triozidae) life history, relationship to plant diseases, and management strategies. Terr. Arthropod Rev. 87-111.

5. Butler, C. D., and Trumble, J. T. 2012. Spatial dispersion and binomial sequential sampling for the potato psyllid (Hemiptera: Triozidae) on potato. Pest Manage. Sci. 68:865-869.

6. Byamukama, E., Gibson, R. W., Aritua, V., and Adipala, E. 2004. Withincrop spread of sweet potato virus disease and the population dynamics of its whitefly and aphid vectors. Crop Prot. 23:109-116.

7. Cameron, P. J., Surrey, M. R., Wigley, P. J., Anderson, J. A., D. Heartnett, D. E., and Wallace, A. R. 2009. Seasonality of Bactericera Cockerelli in potatoes (Solanum tuberosum) in South Auckland, New Zeal. J. Crop Hortic. Sci. 37:295-301.

8. Crosslin, J. M., Hamm, P. B., Eggers, J. E., Rondon, S. I., Sengoda, V. G., and Munyaneza, J. E. 2012. First report of zebra chip disease and 'Candidatus Liberibacter solancearum' on potatoes in Oregon and Washington State. Plant Dis. 96:452.

9. Crosslin, J. M., Lin., H., and Munyaneza, J.E. 2011. Detection of 'Candidatus Liberibacter solanacearum' in the potato psyllid, Bactericera cockerelli (Sulc) by conventional and real-time PCR. Southwest. Entomol. 36:125-135.

10. Crosslin, J. M., Olsen, N., and Nolte, P. 2012. First report of zebra chip disease and 'Candidatus Liberibacter solnacearum' on potatoes in Idaho. Plant Dis. 96:453.

11. Glick, P. A. 1939. The distribution of insects, spiders, and mites in the air. U.S. Dep. Agric. Tech. Bull. No. 673.

12. Goolsby, J. A., Adamczyk, J. J., Crosslin, J.M.. Toxclair, N. N., Anciso, J. R., Bester, G. G., Bradshaw, J. D., Bynum, E. D., Carpiom, L. A., Henne, D. C., Joshi, A., Munyaneza, J. E., Porter, P, Sloderbeck, P. E., Supak, J. R., Rush, C. M., Willet, F. J., Zachmann, B. J., and Zens, B. A. 2012. Seasonal population dynamics of potato psyllid (Hemiptera: Triozidae) and its associated pathogen 'Candidatus Liberibacter solancearum' in potatoes in the southern great plains of North America. J. Econ. Entomol. 105:1268-1276.

13. Goolsby, J. A., Bextine, B., Munyaneza, J. E., Setamou, M., Adamczyk, J., and Bester, G. 2007. Seasonal abundance of sharpshooters, and psyllids associated with potatoes affected by zebra chip disorder. Subtrop. Plant Sci. 59:15-23.

14. Groves, R. L., Wlagenbach, J. F., Moyer, J. W., and Kennedy, G. G. 2003. Seasonal dispersal pattern of Frankliniella fusca (Tysanoptra: Thripidae) and tomato spotted wilt virus occurrence and Central and eastern North
Carolina. J. Econ. Entomol. 96:1-11.

15. Hall, D. G. 2009. An assessment of yellow sticky cards traps as indicators of the abundance of adult Diaphorina citri (Hemiptera: Psyllidae) in citrus. J. Econ. Entomol. 102:446-452.

16. Hall, D. G., Setamou, M., and Mizell, R. 2010. A comparison of sticky traps for monitoring Asian citrus psyllid (Diaphorina citri Kuwayama). Crop Prot. 29:13411346.

17. Hansen, A. K., Trumble, J. T., Stouthamer, R., and Paine, T. D. 2008. A new huanglongbing species, 'Candidatus Liberibacter psyllaurous', found to infect tomato and potato, is vectored by the psyllid Bactericera cockerelli (Sulc). Appl. Environ. Microbiol. 74:5862-5865.

18. Heinz, M. K., Parrella, M. P., and Newman, J. P. 1992. Time efficient use of sticky traps in monitoring insect populations. J. Econ. Entomol. 85:2263-2269.

19. Held, D. W., and Boyd, D. W. 2008. Evaluation of traps and insecticides to prevent gall induction by Gynaikothrips uzeli Zimmerman (Thysanoptera: Phlaeothripidae) on Ficus bemjamina. Pest Manage. Sci. 64:133140 .

20. Henne, D., Anciso, J. Bradshaw, J., Whipple, S., Carpio, L. Richmond, J., Walker, S., Porter, P., Barrett, S., Willet, J., Mathews, J., Deroo, K., Seger, P., Crosslin, J., Hamlin, L., and Goolsby, J. 2012. Overview of the 20112012 psyllid area-wide monitoring program. Pages 1-4 in: Proc. 12th Annu. Zebra Chip Rep. Session. F. Workneh, A. Rashed, and C. M. Rush, eds. San Antonio, TX.

21. Henne, D. C., Paetzold, L., Workneh, F., and C. M. Rush. 2011. Evaluation of potato psyllid cold tolerance, overwintering survival, sticky trap sampling, and effects of LSO on potato psyllid alternate host plants. Pages 149-153 in: Proc. 10th Annu. Zebra Chip Rep. Session. F. Workneh and C. M. Rush, eds. Dallas, Texas.

22. Henne, D. C., Workneh, F., and Rush, C. M. 2012. Spatial patterns and spread of potato zebra chip disease in the Texas Panhandle. Plant Dis. 96:748-956.

23. Hosmer, D. W., and Lemeshaw, S. 2000. Applied Logistic Regression, 2nd ed. John Wiley, New York.

24. Knowlton, J. F. 1933. Length of adult life of Paratrioza cockerelli (Sulc). J. Econ. Entomol. 26:730.

25. Knowlton, G. F., and Janes, M. J. 1931. Studies on the biology of Paratrioza cockerelli (Sulc). Ann. Entomol. Soc. Am. 24:283-291.

26. Kuhar, T. P., and Youngman, R. R. 1998. Olson yellow sticky trap: Making tool for sampling western corn rootworm (Coleoptra: Chrysomelidae) adults in field corn. J. Econ. Entomol. 91:957-963.

27. Liefting, L. W., Perez-Egusquia, Z. C., Clover, G. R. G., and Anderson, J. A. D. 2008. A new 'Candidatus' Liberibacter species in Solanum tuberosum in New Zealand. Plant Dis. 92:1474.

28. Liefting, L. W., Weir, B. S., Pennycook, S. R., and Clover, R. G. 2009. 'Candidatus Liberibacter solanecearum' associated with plants in the family of Solanaceae. Int. J. Syst. Evol. Microbiol. 59:2274-2276.

29. Lin, H., and Gudmestad, N. C. 2013. Aspects of pathogen genomics, diversity, epidemiology, vector dynamics, and disease management for a newly emerged disease of potato: Zebra chip. Phytopathology 103: 524-537.

30. List, G. M. 1939. The effect of temperature upon egg deposition, egg hatch and nymphal development of Paratrioza cockerelli (Sulc). J. Econ. Entomol. 32:30-36.

31. Munyaneza, J. E. 2012. Zebra chip disease of potato: Biology, epidemiology, and management. Am. J. Pot. Res. 89:329-350.

32. Munyaneza, J. E., Buchman, J. L., Sengoda, V. G., Fisher, T. W., and Pearson, C. C. 2011. Susceptibility of selected potato varieties to zebra chip. Am. J. Pot. Res. 88:435-440.

33. Munyaneza, J. E., Buchman, J. L., Sengoda, V. G., Goolsby, J. A., Ochoa, A. P., Trevino, J., and Schuster, G. 2012. Impact of potato planting time on incidence of potato zebra chip disease in the Lower Rio Grande Valley of Texas. Southwest. Entomol. 37:253-262.

34. Munyaneza, J. E., Buckman, J. L., Upton, J. E., Goolsby, J. A., Crosslin, J. M., Gerhard, B., Miles, G. P., and Sengoda, V. G. 2008. Impact of different potato psyllid population on zebra chip disease intensity, severity, and potato yield. Subtrop. Plant Sci. 60:27-37.

35. Munyaneza, J. E., Crosslin, J. M., and Upton, J. E. 2007. Association of Bactericera cockerelli with "zebra chip", a new potato disease in southwestern United States. J. Econ. Entomol. 100:656-663.

36. Munyaneza, J. E., Sengoda, V. G., Buchman, J. L., and Fisher, T. W. 2011. Effects of temperature on 'Candidatus Liberibacter solanacearum' and zebra chip potato disease symptom development. Plant Dis. 96:18-23.

37. Murphy, A. F., Rondon, S. I., and Jensen, A. S. 2013. First report of potato psyllids, Bactericera cockerelli, overwintering in the Pacific Northwest. Am. J. Pot. Res. 90:294-296.

38. Nachappa, P., Shapiro, A. A., and Tamborindeguy, C. 2012. Effect of 'Candidatus Liberibacter solanacearum' on fitness of its host vector, Bactericera cockerelli (Hemiptera: Triozidae), on tomato. Phytopathology 102:41-46. 
39. Pletsch, D. J. 1947. The potato psyllid Paratrioza cockerelli (Sulc), its biology and control. Mont. Agric. Exp. Stn. Bull. 446.

40. Power, A. G., Rodriguiz, C. M., and Gomez, R. 1992. Evaluation of two leafhoppers sampling methods for predicting the incidence of leafhoppertransmitted virus of maize. J. Econ. Entomol. 85:411-415.

41. Rashed, A., Wallis, C. M., Paetzold, L., Workneh, F., and Rush, C. M. 2013. Zebra chip disease and potato biochemistry: Tuber physiological changes in response to 'Candidatus Liberibacter solanacearum' infection over time. Phytopathology 103:419-426.

42. Rehman, M. Melgar, J. C. Rivera, J. M., Idris, A. M., and Brown, J. K. 2010. First report of 'Candidatus Liberibacter psyllaurous' or ' $\mathrm{Ca}$. Liberibacter solanacearum' associated with severe foliar chlorosis, curling, and necrosis and tuber discoloration of potato plants in Honduras. Plant Dis. 94:376.

43. Romney, V. E. 1939. Breeding areas of the tomato psyllid, Paratrioza cockerelli (Sulc). J. Econ. Entomol. 32:150-151.

44. Secor, G. A., Lee, I. M., Bottner, K. D., Rivera-vera, V., and Gudemsatd, N. C. 2006. First report of a defect of processing potatoes in Texas and Nebraska associated with a new phytoplasma. Plant Dis. 90:377.

45. Secor, G. A., and Rivera, V. V. 2004. Emerging diseases of cultivated potato and their impact on Latin America. Rev. Latinoam. Papa (Suppl.) 1:1-8.

46. Secor, G. A., Rivera, V. V., Abad, J. A. Lee, I.-M., Clover, G. R. G., Liefting, L. W., Li, X., and Boer, S. H. 2009. Association of 'Candidatus Liberibacter solancearum' with zebra chip disease of potato established by graft transmission, electron microscopy, and PCR. Plant Dis. 93:574-583.

47. Tabachnick, B. G., and Fidell, L. S. 2007. Using Multivariate Analysis, 5th ed. Pearson, New York.
48. Wallis, R. L. 1946. Seasonal occurrence of potato psyllid in the North Platte Valley. J. Econ. Entomol. 39:689-694.

49. Wallis, R. L. 1955. Ecological studies on the potato psyllid as a pest of potatoes. U.S. Dep. Agric. Tech. Bull. 1107.

50. Wen, A., Mallik, I., Alvarado, V. Y., Pasche, J. S., Wang., X., Li, W., Levi, L., Lin, H., Scholthoff, H. B., Mirkov, T. E., Rush, C. M., and Gudmestad, N. C. 2009. Detection, distribution, and genetic variability of 'Candidatus' Liberibacter species associated with zebra complex disease of potato in North America. Plant Dis. 93:1102-1115.

51. Whipple, S., Bradshaw, J. D., and Harveson, B. 2012. Cold tolerance in potato psyllids. Pages 191-193 in: Proc. 12th Annu. Zebra Chip Rep. Session. F. Workneh, A. Rashed, and C. M. Rush, eds. San Antonio, TX.

52. Workneh, F., Henne, D. C., Childers, A. C., Paetzold, L., and Rush C. M. 2012. Assessments of edge effect in intensity of potato zebra chip disease. Plant Dis. 96:943-947.

53. Workneh, F., Henne, D. C., Paetzold, L., and Rush, C. M. 2011. Effect of temperature on potato psyllid reproduction and Liberibacter titer level in tubers. (Abstr.) Phytopathology 101:S194.

54. Workneh, F., Mirik, M., Rashed, A., Hamm, P. B., Ansley, J., and Rush, C. M. 2012. Potato zebra chip in the Pacific Northwest: Impact and probable psyllid source assessments. (Abstr.) Phytopathology 102:S4.137.

55. Zens, B., Rush, C. M., Henne, D. C., Workneh, F., Bynum, E., Nansen, C., and Gudmestad, N. C. 2010. Efficacy of seven chemical programs to control potato psyllids in the Texas Panhandle. Pages 83-87 in: Proc. 10th Annu. Zebra Chip Rep. Session. F. Workneh and C. M. Rush, eds. Dallas, TX. 